\title{
Macrozoobenthic communities of the saline Bolshaya Samoroda River (Lower Volga region, Russia): species composition, density, biomass and production
}

\author{
Larisa V. Golovatyuk (1) - Tatiana D. Zinchenko • Larisa B. Nazarova $($ D
}

Received: 10 May 2019/Accepted: 13 September 2019

(C) Springer Nature B.V. 2019

\begin{abstract}
We investigated species composition, density, biomass and estimated production of macrozoobenthos communities in the middle and mouth reaches of the saline Bolshaya Samoroda River (Volgograd region, Russia) from May 2013 to April 2014. A total of 30 euryhaline and halophilic taxa were found during the study period. There were significant differences in the species composition between both study sites that could be explained by differences in ecological conditions. The production of
\end{abstract}

Handling Editor: Télesphore Sime-Ngando.

L. V. Golovatyuk $(\bowtie) \cdot$ T. D. Zinchenko

Institute of Ecology of the Volga River Basin, Russian

Academy of Sciences, Komzina str. 10, Togliatti, Russia 445003

e-mail: gollarisa@mail.ru

T. D. Zinchenko

e-mail: zinchenko.tdz@yandex.ru

L. B. Nazarova

Potsdam University, Am Neuen Palais 10,

14469 Potsdam, Germany

e-mail: nazarova_larisa@mail.ru

L. B. Nazarova

Alfred Wegener Institute, Helmholtz Centre for Polar and Marine Research, Research Unit Potsdam, Telegrafenberg A43, 14473 Potsdam, Germany

\section{B. Nazarova}

Kazan Federal University, Kremlyovskaya str., 18, Kazan, Russia 420018 macrozoobenthos in the middle reach was $22.54 \mathrm{~g}$ dry $\mathrm{w} \mathrm{m}^{-2} \mathrm{yr}^{-1}$, and in the mouth reach the production was $117 \mathrm{~g}$ dry $\mathrm{wt} \mathrm{m}^{-2} \mathrm{yr}^{-1}$. In all seasons of the year at both sites, the greatest contribution to benthic production was made by the same taxonomic groups. Diptera dominated at both sites. Amphipods were abundant only in the middle reach. In the middle reach, the greatest contributions to production were made by Gammarus lacustris, Sphaeromias pictus and Glyptotendipes salinus, and in the mouth reach, Microchironomus deribae, Tanytarsus kharaensis and Chironomus salinarius contributed to benthic production the most.

Keywords Saline river - Macrozoobenthos community $\cdot$ Density $\cdot$ Biomass $\cdot$ Production

\section{Introduction}

The importance of stream productivity for surrounding terrestrial habitats has been shown in many studies (Nakano et al. 1999; Nazarova et al. 2004; Baxter et al. 2005; Ballinger and Lake 2006; Moore et al. 2007; Benke and Huryn 2010; Zinchenko et al. 2014; Benke and Huryn 2017; Golovatyuk et al. 2018). These works have demonstrated that rivers can supply the surrounding terrestrial ecosystems with nutrients and energy via the emergence of aquatic insects. However, 
all these studies were conducted on freshwater lotic systems. In contrast to freshwater streams, practically no studies examining energy and matter fluxes from saline rivers to the surrounding landscape have been performed until now (Zinchenko et al. 2014), although saline rivers are widespread in arid zones of the world and play a large role in maintaining the biodiversity of these ecologically sensitive regions (Moreno et al. 2001; Piscart et al. 2005; Palmer and Bennett 2006). Among the various groups of aquatic organisms living in saline rivers, macrozoobenthic organisms play an important role in the flow of matter and energy from aquatic to terrestrial ecosystems, as they serve as a food source for a number of species of fish, waterfowl, reptiles and mammals (Ballinger and Lake 2006; Kasatkina and Shubin 2012; Sukharev 2015). Benthic invertebrates in saline rivers have a physiological tolerance to salinity gradients and are adapted to habitats that undergo constant changes in abiotic factors (Velasco et al. 2006; Golovatyuk and Shitikov 2016).

The arid region around the hyperhaline Lake Elton (Caspian lowland, southeastern European Russia) includes seven saline rivers that run into the lake. These rivers are used as feeding places not only by indigenous birds but also by migratory waterfowl on their transcontinental and inland migration routes. During the migration stops, many species of sandpipers, such as the common Charadrius hiaticula, Ch. dubius, Ch. alexandrines and Phalaropus lobatus, have high abundances here (Kasatkina and Shubin 2012; Sukharev 2015). Surveys have shown that macrozoobenthic organisms play a main role in the diet of many species of migratory waders (Andrei et al. 2009; Kasatkina and Shubin 2012). In the rivers of the catchment area of the lake, Elton chironomids accounted for up to $48-95 \%$ of the diet of different species of birds, and Ephydridae accounted for up to 18-96\% (Sukharev 2015).

Currently, the reduction in the populations of some species of wader fauna is associated with a deterioration in the feeding conditions that occur at their migratory stop locations (Brown et al. 2001; Fellows et al. 2001; International Wader Study Group 2003), which makes an evaluation of the macrozoobenthic production of saline rivers that are used by migratory birds, such as rivers in the catchment of the hyperhaline Lake Elton, especially important.
The main goal of our work was to study the species composition, seasonal dynamics of density and biomass of the main groups of macrozoobenthos in the middle reaches and at the mouth of the saline Bolshaya Samoroda River that belongs to the catchment of the hyperhaline Lake Elton and to estimate their production in relation to the salinity gradient and to other ecological conditions.

\section{Materials and methods}

Study site

The Bolshaya Samoroda (B. Samoroda) River $\left(49^{\circ} 07^{\prime}\right.$, $46^{\circ} 47^{\prime}$ ) is a saline river in the catchment of the hyperhaline Lake Elton, located in the Volgograd region of the Russian Federation (Fig. 1). This is an arid area with an annual precipitation below $280 \mathrm{~mm}$ $\mathrm{y}^{-1}$. The climate is continental with an air temperature minimum in January of $-36.1^{\circ} \mathrm{C}$ and a maximum in August of $41.1^{\circ} \mathrm{C}$ (Vodno-bolotny... 2005). The B. Samoroda River is $24.3 \mathrm{~km}$ long, with a catchment area of $130 \mathrm{~km}^{2}$. The B. Samoroda River has a permanent flow in the middle and lower reaches, whereas the flow is intermittent at the upper reaches, especially during dry years.

Two sampling stations with different levels of salinity were selected for the present study: Site 1 in the middle reach and Site 2 in the mouth of the river. The main characteristics and hydrochemical parameters of the B. Samoroda River at Sites 1 and 2 are given in Table 1 .

Sampling and laboratory analysis

Two integrated samples for quantitative of macrozoobenthos analysis were taken monthly from May 2013 to April 2014 using Ekman-type grab sampler (surface area $25 \mathrm{~cm}^{2}$ ) (Zinchenko et al. 2014). Each integrated sample consisted of eight samples taken from one sampling station at one date. In total, we sampled and analyzed 48 integrated samples. Average monthly density and biomass of macrozoobenthos at each sampling site were estimates from the integrated monthly samples.

Samples were washed in the field using a mesh screen with 300-310- $\mu \mathrm{m}$ mesh size and preserved in $4 \%$ formaldehyde. Benthic organisms were 


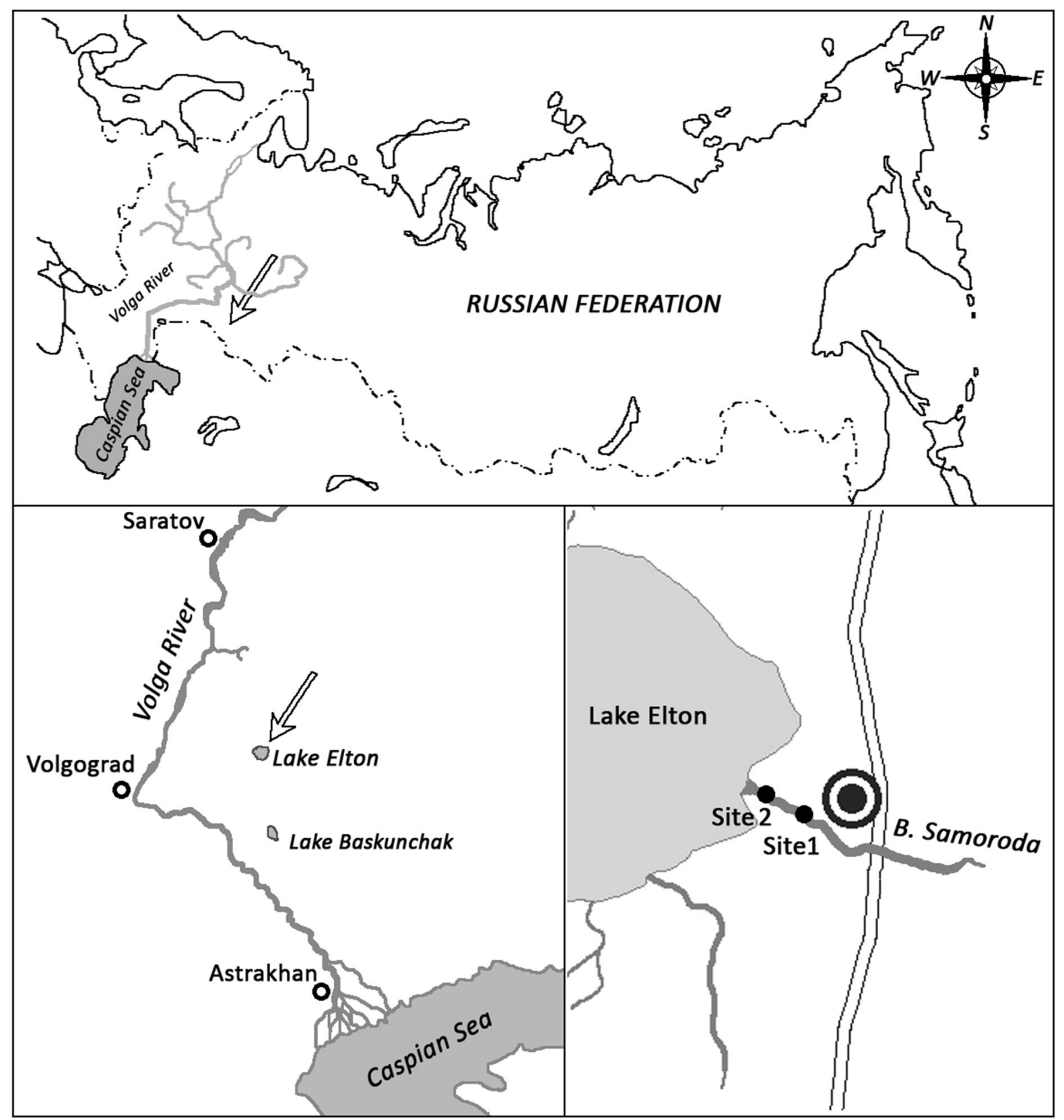

Fig. 1 Map of the study area

handpicked in laboratory under a stereomicroscope, identified, counted and weighed using electronic scales (Pioneer TM) with a resolution of $0.01 \mathrm{~g}$. Ecological information on the macrozoobenthos species was taken from Zinchenko et al. (2014), Golovatyuk and Shitikov (2016), Szadziewski et al. (2016), and Zinchenko et al. (2017).
Concentration of chlorophyll- $a$ was measured in May, August and September 2013 by spectrophotometry, using extraction in acetone (Nomokonova et al. 2013). Concentration of chlorophyll- $a$ was measured to assess the relationship between primary production and the production of macrozoobenthos.

The number of generations of Gammarus lacustris during a year of investigation (May 2013-April 2014) 
Table 1 Characteristics and hydrochemical parameters (minmax) of the sampling sites of the B. Samoroda River from May 2013 to April 2014

\begin{tabular}{|c|c|c|}
\hline Parameter & Site 1 & Site 2 \\
\hline Depth (m) & $0.2-1.0$ & $0.05-0.80$ \\
\hline Width (m) & $3.5-8.0$ & $5.0-35.0$ \\
\hline Temperature $\left({ }^{\circ} \mathrm{C}\right)$ & $4.0-25.6$ & $4.0-27.6$ \\
\hline Current velocity $\left(\mathrm{m} \mathrm{s}^{-1}\right)$ & $0.2-0.24$ & $0.02-0.03$ \\
\hline Vegetation (\%) & $30-70$ & $10-30$ \\
\hline $\mathrm{pH}$ & $7.4-8.2$ & $7.8-8.7$ \\
\hline Dissolved $\mathrm{O}_{2}\left(\mathrm{mg} \mathrm{l}^{-1}\right)$ & $6.2-31$ & $6.9-25.3$ \\
\hline Salinity $\left(\mathrm{g} \mathrm{l}^{-1}\right)$ & $5.2-8.5$ & $5.8-26.3$ \\
\hline Chlorophyll-a $\left(\mathrm{mg} \mathrm{m}^{-3}\right)$ & $7.3-19.4$ & $4.9-18.8$ \\
\hline $\mathrm{Na}^{+}+\mathrm{K}^{+}\left(\mathrm{g} \mathrm{l}^{-1}\right)$ & $1.44-2.09$ & $1.86-5.5$ \\
\hline $\mathrm{Ca}^{2+}\left(\mathrm{g} \mathrm{l}^{-1}\right)$ & $0.28-0.36$ & $0.3-0.6$ \\
\hline $\mathrm{Mg}^{2+}\left(\mathrm{g}^{-1}\right)$ & $0.22-0.41$ & $0.3-2.6$ \\
\hline $\mathrm{Cl}^{-}\left(\mathrm{g}^{-1}\right)$ & $3.22-3.91$ & $3.36-15.9$ \\
\hline $\mathrm{SO}_{4}{ }^{2-}\left(\mathrm{g}^{-1}\right)$ & $0.41-1.44$ & $0.51-1.28$ \\
\hline $\mathrm{HCO}\left(\mathrm{g} \mathrm{l}^{-1}\right)$ & $0.48-0.59$ & $0.43-0.62$ \\
\hline Total P (mg 1 $\left.{ }^{-1}\right)$ & $1.06-2.0$ & $1.1-1.43$ \\
\hline $\mathrm{NH}_{4}{ }^{+}-\mathrm{N}\left(\mathrm{mg} \mathrm{l}^{-1}\right)$ & $1.06-2.33$ & $0.18-1.8$ \\
\hline $\mathrm{NO}_{3}{ }^{-}-\mathrm{N}\left(\mathrm{mg} \mathrm{l}^{-1}\right)$ & $0.06-1.06$ & $0.09-1.03$ \\
\hline
\end{tabular}

was estimated by the method described by Bazikalova (1945).

At each sites of B. Samoroda River, we used field analytical instruments for measuring $\mathrm{pH}$ (HANNA $\mathrm{pH}$ Tester HI 98127), oxygen content (HANNA Oximeter HI 9146) and water velocity (ISP-1). Hydrochemical analysis (Table 1) was performed in the Hydrochemical Laboratory "Center for Monitoring of Water and Geological environment" in Samara, Russian Federation. Water temperature was measured at each sampling site and date at 15-min intervals during 24 h (WTW, MultiLine, Germany). For our study, we used an average monthly temperature. Overgrowth or macrophytes density at the sampling sites was estimated as a ratio of the area occupied by macrophytes at the 5-m-long river section to the entire area of this section, expressed in \%.

Calculation of macrozoobenthos production

Daily production $P\left(\mathrm{~g} \mathrm{~m}^{-2} \mathrm{day}^{-1}\right)$ of macrozoobenthos was estimated as
$P=G B$

where $G\left(\right.$ day $\left.^{-1}\right)$ is the daily instantaneous growth rate and $B\left(\mathrm{~g} \mathrm{~m}^{-2}\right)$ is the biomass and dry weight (Benke 1998). The growth rate for family Ceratopogonidae, subfamilies Orthocladiinae and Chironominae, other Diptera, Coleoptera and Heteroptera was calculated by equations developed by Golubkov (2000):

Orthocladiinae : $G=0.0126 e^{0.121 T}$

Chironominae $: G=0.0084 e^{0.149 T}$

Ceratopogonidae : $G=0.0041 e^{0.116 T}$

Diptera(others) $: G=0.0075 e^{0.143 T}$

Coleoptera : $G=0.0049 e^{0.092 T}$

Heteroptera : $G=0.007 e^{0.095 T}$

where $\mathrm{T}\left({ }^{\circ} \mathrm{C}\right)$ is temperature.

These equations can be used to express calculations of production of aquatic insects (Golubkov 2000) when the data on growth rates are available not for all species of aquatic organisms from the studied macrozoobenthos community.

The production of Oligochaeta was calculated using a growth rate of 0.03 (Zaika 1972). A growth rate of 0.03 was used to calculate the production of $G$. lacustris based on studies from the brackish Lake Shira (Yemelyanova et al. 2000).

Monthly production was calculated by multiplying the average daily production for all sampling dates by 31 days (January, March, May, July, August, October and December), 30 days (April, June, September and November) or 28 days (February) (Zinchenko et al. 2014).

Numerical methods

Detrended correspondence analysis (DCA) with detrending by segments was performed on the macrozoobenthos data (rare taxa downweighted) to explore the main pattern of taxonomic variation among sites and to determine the lengths of the sampled environmental gradients, from which we decided whether unimodal or linear statistical techniques would be the most appropriate for the data analysis (Birks 1995; Palagushkina et al. 2012, 2017; Frolova et al. 2013). 
The gradient length of species scores was relatively long. DCA axes 1 and 2 were 4.265 and 2.525 standard deviation units, respectively, indicating that numerical methods based on a unimodal response model were the most appropriate to assess the variation in the structure of zoobenthos assemblages (ter Braak 1995).

Relationships between macrozoobenthos distribution and environmental variables were assessed using a set of canonical correspondence analyses (CCA) with each environmental variable as the sole constraining variable (Nazarova et al. 2015). The percentage of the variance explained by each variable was calculated. Manual forward selection was used to identify a subset of environmental variables that explained significant variations in the macrozoobenthos data (Nazarova et al. 2017). The statistical significance of each forward-selected variable was tested by a Monte Carlo permutation test (999 unrestricted permutation, $p \leq 0.05$ ) (ter Braak 1990). With the selection of each variable in forward selection, the relative importance of the remaining variables is re-evaluated. Relationships between the significant environmental variables and the individual CCA axes were examined through correlation coefficients and $t$ values. Both DCA and CCA were performed using CANOCO 4.5 (ter Braak and Šmilauer 2002b).

\section{Results}

Species composition

In total, 30 taxa of benthic invertebrates were found during the entire study period. Diptera and Oligochaeta were the richest taxonomic groups, with 18 and 5 species, respectively. Four species of Coleoptera, two species of Heteroptera and one species of Amphipoda were also recorded.

In the middle reaches (Site 1), 18 taxa were found, and 21 taxa were found at the mouth site (Site 2). There was a significant faunistic difference between the two sampling sites: 9 species were found only at Site 1 and 13 species only at Site 2. At Site 1, G. lacustris, Limnodrilus profundicola and Sphaeromias pictus had the highest frequencies $(>50 \%)$, while at Site 2, Cricotopus gr. sylvestris, Chironomus salinarius, Tanytarsus kharaensis, Cricotopus salinophilus and Microchironomus deribae had the highest frequencies (Tables 2, 3).

Ordination of the data

CCA with all seven environmental variables (water temperature, water velocity, total phosphorus, overgrowth-macrophyte density, water depth, $\mathrm{pH}$ and salinity) resulted in a CCA axis 1 of 0.713 and a CCA axis 2 of 0.267 , explaining $31.5 \%$ and $43.4 \%$ of the variance in the data, respectively (Table 4). Juggins (2013) suggests that a ratio of eigenvalues of CCA axes 1 and $2(\lambda 1 / \lambda 2)$ below 1 indicates that potential factors affecting assemblages besides the explored variables have not been assessed. In our study, this ratio is $2.67(\lambda 1 / \lambda 2=0.713 / 0.267)$, which indicates that the most important explanatory variables are most likely included in the analysis.

The forward selection reveals that four of seven explanatory variables were statistically significant $(p \leq 0.05)$ : vegetation, water velocity, $\mathrm{pH}$ and salinity (Table 5).

The CCA eigenvalues for axes $1(0.679)$ and 2 (0.241) constrained by the four significant environmental variables (Table 4) are only slightly lower than those obtained for axes 1 and 2 from CCA for all seven environmental variables, suggesting that the four selected variables explain the major gradients in the macrozoobenthic community data.

Axis 1 of the CCA most strongly correlates with vegetation (Table 6). The canonical coefficient is the highest in absolute value, and the $t$ value is greater than 2.1 , the critical value for a $t$ test at the $5 \%$ significance level (ter Braak and Šmilauer 2002a). Axis 2 correlates with vegetation, water velocity, $\mathrm{pH}$ and salinity. Axis 3 correlates with $\mathrm{pH}$ and water velocity, and axis 4 correlates with salinity.

A CCA biplot of the sample scores shows that both sampling sites are plotted separately, confirming their taxonomic differences: All samples taken from Site 1 (S1) are grouped in the right part of the biplot, and all samples taken from Site 2 (S2) are grouped in the left part of the diagram. Additionally, the distribution of the samples taken at different dates reflects a seasonal shift in the taxonomic composition of the benthic communities: Samples taken in the early vegetation season are plotted in the lower part of the biplot when the water velocity was higher and the salinity lower, and the samples from the late season are grouped in the 
Table 2 List of benthic macroinvertebrates, their frequency $\left(F, \%\right.$ of samples), average density $\left(D\right.$, ind. $\left.\mathrm{m}^{-2}\right)$, average biomass $\left(B, \mathrm{~g}\right.$ dry $\left.\mathrm{wt} \mathrm{m}^{-2}\right)$, summary production $(P$, g dry wt $\mathrm{m}^{-2} \mathrm{yr}^{-1}$ ) and $P / B$ values at Site 1 in the $\mathrm{B}$. Samoroda River from May 2013 to April 2014; salinity ranges at which these taxa were found at the Site 1 of the B. Samoroda River from May 2013 to April $2014\left(S_{\mathrm{B}}, \mathrm{g} \mathrm{l}^{-1}, \min -\max \right)$ and salinity ranges $\left.\left(S, \mathrm{~g} \mathrm{l}^{-1}, \min -\max \right)\right)$ at which these taxa were found in the rivers of the Elton Lake basin during our earlier studies (Golovatuk and Shitikov 2016)

\begin{tabular}{|c|c|c|c|c|c|c|c|}
\hline Taxa & $F$ & $D$ & $B$ & $P$ & $P / B$ & $S_{\mathrm{B}}$ & $S$ \\
\hline \multicolumn{8}{|l|}{ Oligochaeta } \\
\hline Limnodrilus hoffmeisteri Claparede, 1862 & 13 & 60 & 0.002 & 0.014 & 7 & $7.1-7.3$ & $7-13$ \\
\hline Limnodrilus profundicola (Verril, 1871) & 53 & 400 & 0.118 & 0.984 & 8 & $5.2-8.5$ & $5-14$ \\
\hline Limnodrilus udekemianus Claparède, 1862 & 7 & 10 & 0.008 & 0.07 & 9 & $5.2-5.6$ & $4-7$ \\
\hline Nais elinguis Müller, 1773 & 13 & 217 & 0.029 & 0.246 & 8 & $5.6-7.3$ & $4-26$ \\
\hline Paranais simplex Hrabe, 1936 & 40 & 1183 & 0.032 & 0.269 & 8 & $5.6-7.8$ & $4-26$ \\
\hline \multicolumn{8}{|l|}{ Malacostraca } \\
\hline Gammarus lacustris Sars, 1863 & 67 & 1570 & 1.86 & 15.34 & 8 & $5.2-8.5$ & $5-16$ \\
\hline \multicolumn{8}{|l|}{ Insecta } \\
\hline \multicolumn{8}{|l|}{ Heteroptera } \\
\hline Paracorixa concinna (Fieber, 1848) & 27 & 13 & 0.012 & 0.18 & 15 & $7.3-7.6$ & $6-13$ \\
\hline \multicolumn{8}{|l|}{ Coleoptera } \\
\hline Hydrobius fuscipes Leach, 1815 & 7 & 3 & 0.002 & 0.03 & 15 & $7.3-7.6$ & $7-16$ \\
\hline \multicolumn{8}{|l|}{ Diptera } \\
\hline \multicolumn{8}{|l|}{ Psychodidae } \\
\hline Psychoda sp. & 7 & 57 & 0.003 & 0.22 & 73 & $7.3-7.6$ & $7-26$ \\
\hline \multicolumn{8}{|l|}{ Ceratopogonidae } \\
\hline Culicoides riethi Kieffer, 1914 & 20 & 87 & 0.001 & 0.016 & 16 & $7.3-7.8$ & $4-32$ \\
\hline Dasyhelea sp. & 7 & 3 & 0.002 & 0.005 & 3 & $7.3-7.6$ & $7-17$ \\
\hline Sphaeromias pictus (Kieffer, 1919) & 53 & 473 & 0.119 & 1.93 & 16 & $5.6-8.5$ & $5-12$ \\
\hline \multicolumn{8}{|l|}{ Chironomidae } \\
\hline Cricotopus ornatus (Meigen, 1818) & 20 & 107 & 0.015 & 1.02 & 68 & $7.1-7.8$ & $7-16$ \\
\hline Cricotopus salinophilus Zinchenko. Makarchenko et Makarchenko, 2009 & 13 & 17 & 0.002 & 0.14 & 70 & $7.3-7.8$ & $4-32$ \\
\hline Cricotopus sp. & 13 & 20 & 0.0017 & 0.118 & 69 & $7.3-7.8$ & $4-14$ \\
\hline Glyptotendipes salinus Michailova, 1987 & 27 & 33 & 0.027 & 1.31 & 49 & $5.6-7.8$ & $4-29$ \\
\hline Chironomus gr. plumosus & 7 & 3 & 0.013 & 0.551 & 42 & $7.3-7.6$ & $4-10$ \\
\hline Microchironomus deribae (Freeman, 1957) & 20 & 17 & 0.001 & 0.076 & 76 & $6.6-7.8$ & $5-29$ \\
\hline Tanytarsus kharaensis Zorina et Zinchenko, 2009 & 7 & 7 & 0.0002 & 0.019 & 95 & $7.6-7.8$ & $5-26$ \\
\hline All taxa & & 4280 & 2.25 & 22.54 & & & \\
\hline
\end{tabular}

upper part of the diagram when the conditions became less turbulent and salinity and $\mathrm{pH}$ increased (Fig. 2).

The distribution of benthic taxa along the CCA axes reflects their ecological spectra (Fig. 3). In the bottom right part are typical phytophilic taxa that can tolerate higher water velocity but are less tolerant to high salinity and pH: G. lacustris, Cricotopus ornatus, Cricotopus sp., Culicoides riethi, Limnodrilus hoffmeisteri, Hydrobius fuscipes, Dasyhelea sp. and Paracorixa concinna.
Along the positive scores of CCA axis 1 in the right part of the diagram are the phytophilic taxa that are indifferent to salinity fluctuation within the frames of the investigated ecological conditions: L. profundicola, Paranais simplex and S. pictus. In the bottom left part of the biplot, the taxa that are indifferent to the presence of vegetation prefer lower salinity and can survive higher water velocities that are grouped: Chironomus aprilinus, Mallochohelea sp., Psychoda sp., Hygrotus enneagrammus, Berosus fulvus, etc. 
Table 3 List of benthic macroinvertebrates, their frequency $\left(F, \%\right.$ of samples), average density $\left(D\right.$, ind. $\left.\mathrm{m}^{-2}\right)$, average biomass $\left(B, \mathrm{~g}\right.$ dry $\left.\mathrm{wt} \mathrm{m}^{-2}\right)$, summary production $(P$, g dry wt $\mathrm{m}^{-2} \mathrm{yr}^{-1}$ ) and $P / B$ values at Site 2 in the $\mathrm{B}$. Samoroda River from May 2013 to April 2014, the basin of Lake Elton, Russian Federation. Salinity ranges $\left(S_{\mathrm{B}}, \mathrm{g} 1^{-1}\right.$,

\begin{tabular}{lllllllllllll}
\hline Taxa & $F$ & $D$ & $B$ & $P$ & $P /$ & $S_{\mathrm{B}}$ & $S$ & \\
\end{tabular}

Oligochaeta

Nais elinguis Müller, 1773

Paranais simplex Hrabe, 1936

Insecta

Heteroptera

Paracorixa concinna (Fieber, 1848)

Sigara lateralis (Leach, 1817)

Coleoptera

Berosus fulvus Kuwert, 1888

Berosus sp.

Hygrotus enneagrammus (Ahrens, 1833)

Diptera

Psychodidae

Psychoda sp.

Ceratopogonidae

Culicoides riethi Kieffer, 1914

Mallochohelea sp.

Palpomyia schmidti Goetghebuer, 1934

Sphaeromias pictus (Kieffer, 1919)

Chironomidae

Cricotopus salinophilus Zinchenko, Makarchenko et Makarchenko, 2009

Cricotopus gr. sylvestris

Glyptotendipes salinus Michailova, 1987

Chironomus aprilinus Meigen, 1838

Chironomus salinarius Kieffer, 1915

Microchironomus deribae (Freeman, 1957)

Tanytarsus kharaensis Zorina et Zinchenko, 2009

Dolichopodidae

Ephydridae

Ephydra sp.

All taxa $\min -\max )$ in water of the Site 2 where benthic species were found in the B. Samoroda River from May 2013 to April 2014 and salinity ranges $\left(S, \mathrm{~g}^{-1}\right.$, min-max) in water areas where benthic species were found in rivers of the Lake Elton basin (Golovatyuk and Shitikov 2016)

$\begin{array}{lllllll}27 & 17 & 0.0003 & 0.002 & 7 & 8-26.3 & 4-26 \\ 20 & 80 & 0.0004 & 0.004 & 10 & 6.1-26.3 & 4-26\end{array}$

$\begin{array}{rrllrll}7 & 3 & 0.011 & 0.05 & 5 & 5.8-6.1 & 6-13 \\ 33 & 33 & 0.049 & 0.61 & 12 & 8-26.3 & 8-29 \\ & & & & & & \\ 7 & 40 & 0.025 & 0.37 & 15 & 10.3-10.8 & 7-32 \\ 13 & 30 & 0.022 & 0.35 & 16 & 8.3-10.3 & 8-32 \\ 33 & 17 & 0.007 & 0.1 & 14 & 7.2-14.2 & 7-29\end{array}$

$\begin{array}{lllllll}13 & 13 & 0.002 & 0.17 & 85 & 7.2-8.3 & 7-26\end{array}$

$\begin{array}{lllllll}20 & 23 & 0.0039 & 0.012 & 3 & 6.1-13.5 & 4-32\end{array}$

$\begin{array}{lllllll}7 & 10 & 0.0006 & 0.015 & 25 & 6.1-7.2 & 7-16\end{array}$

$\begin{array}{lllllll}27 & 37 & 0.001 & 0.024 & 24 & 5.8-14.2 & 8-32\end{array}$

$\begin{array}{lllllll}7 & 20 & 0.006 & 0.024 & 4 & 7.2-8.1 & 5-12\end{array}$

$\begin{array}{lllllll}67 & 85 & 0.102 & 5.34 & 52 & 5.8-14.2 & 4-32\end{array}$

$\begin{array}{lllllll}80 & 233 & 0.032 & 1.41 & 44 & 5.8-26.3 & 4-30\end{array}$

$\begin{array}{lllllll}20 & 30 & 0.103 & 0.38 & 4 & 9.2-26.3 & 4-29\end{array}$

$\begin{array}{lllllll}7 & 3 & 0.0009 & 0.024 & 27 & 10.3-10.8 & 4-17\end{array}$

$\begin{array}{lllllll}73 & 1997 & 0.707 & 36.4 & 51 & 5.8-26.3 & 7-41\end{array}$

$\begin{array}{lllllll}60 & 8850 & 0.781 & 49.2 & 63 & 5.8-26.3 & 5-29\end{array}$

$\begin{array}{lllllll}67 & 5283 & 0.441 & 15.47 & 35 & 5.8-26.3 & 5-26\end{array}$

$\begin{array}{lllll}20 & 10 & 0.006 & 0.25 & 42\end{array}$

$\begin{array}{lllllll}40 & 110 & 0.079 & 6.78 & 86 & 7.2-14.2 & 7-90\end{array}$

$\begin{array}{lll}16,924 & 2.38 \quad 117\end{array}$
In the upper left part of the biplot, the taxa that are able to withstand high salinity prefer standing or slowmoving waters and are not dependent on the presence of vegetation that are grouped: $M$. deribae, $T$. kharaensis, Ch. salinarius, C. gr. sylvestris, Sigara lateralis and Nais elinguis.
Density and biomass

The average densities of macrozoobenthos in the river mouth significantly exceeded those in the middle reach in all months except for June (Fig. 4). In the middle reach, the highest density of 14,548 ind. $\mathrm{m}^{-2}$ 
Table 4 Eigenvalues, cumulative \% variance and significance of the CCA axes

\begin{tabular}{|c|c|c|c|c|}
\hline Full data set & Axis 1 & Axis 2 & Axis 3 & Axis 4 \\
\hline Eigenvalues & 0.713 & 0.267 & 0.166 & 0.090 \\
\hline Cumulative $\%$ variance of species data & 31.5 & 43.4 & 50.7 & 54.7 \\
\hline Cumulative percentage variance of species-environment relation & 53.0 & 72.8 & 85.2 & 91.9 \\
\hline Sum of all unconstrained eigenvalues & 2.259 & & & \\
\hline \multicolumn{5}{|l|}{ CCA with four significant variables } \\
\hline Eigenvalues & 0.679 & 0.241 & 0.162 & 0.047 \\
\hline Cumulative $\%$ variance of species data & 29.3 & 39.7 & 46.7 & 48.7 \\
\hline Cumulative percentage variance of species-environment relation & 60.1 & 81.5 & 95.9 & 100.0 \\
\hline Sum of all unconstrained eigenvalues & 2.318 & & & \\
\hline
\end{tabular}

Table 5 Significant variables as identified by manual forward selection in $\mathrm{CCA}$ and the variance they explain

\begin{tabular}{llll}
\hline Variable & Added with selection & $p$ Value estimates & $F$ value \\
\hline Vegetation & 0.675 & 0.002 & 6.573 \\
Water velocity & 0.333 & 0.002 & 2.096 \\
$\mathrm{pH}$ & 0.383 & 0.004 & 1.77 \\
Salinity & 0.163 & 0.03 & 0.991 \\
Total variance explained & 1.554 & & \\
Total variance & 2.318 & & \\
\hline
\end{tabular}

Table 6 Environmental variables, canonical coefficients and $t$ values of significant environmental variables used in the CCA

\begin{tabular}{|c|c|c|c|c|c|c|c|c|}
\hline & \multicolumn{4}{|c|}{ Canonical coefficients } & \multicolumn{4}{|l|}{$t$ values } \\
\hline & Axis 1 & Axis 2 & Axis 3 & Axis 4 & Axis 1 & Axis 2 & Axis 3 & Axis 4 \\
\hline Water velocity & -0.027 & -0.908 & 0.642 & 0.5682 & -0.339 & -3.758 & 3.873 & 0.904 \\
\hline $\mathrm{pH}$ & 0.024 & 0.764 & 1.029 & -0.461 & 0.275 & 2.899 & 5.690 & -0.673 \\
\hline Salinity & 0.087 & 0.478 & 0.244 & 0.988 & 1.213 & 2.184 & 1.632 & 1.743 \\
\hline Vegetation & 1.062 & 1.129 & 0.419 & -0.277 & 10.280 & 3.583 & 1.939 & -0.338 \\
\hline
\end{tabular}

occurred in June, and in the river mouth, the highest density of 53,752 ind. $\mathrm{m}^{-2}$ occurred in September. During the year, the average density of all taxa in the middle reach was 4280 ind. $\mathrm{m}^{-2}$, and in the river mouth reaches the average was 16,924 ind. $\mathrm{m}^{-2}$ (Tables 2, 3).

The average biomass of benthos was the highest at both stations in the summer when the water temperature ranged from 20.8 to $27.6^{\circ} \mathrm{C}$ (Fig. 4). The highest biomass was observed in August at both sites: $6.23 \mathrm{~g} \mathrm{dry} \mathrm{wt} \mathrm{m}^{-2}$ in the middle reaches and $5.84 \mathrm{~g}$ dry $\mathrm{wt} \mathrm{m}^{-2}$ at the river mouth. The average

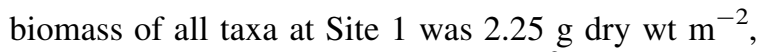
and at Site 2 , it was $2.38 \mathrm{~g}$ dry wt $\mathrm{m}^{-2}$.

In the middle reaches, $G$. lacustris, $P$. simplex and S. pictus constituted up to $75.4 \%$ (3391 ind. $\mathrm{m}^{-2}$ ) of the average benthos density and $G$. lacustris, S. pictus and L. profundicola constituted up to $89.3 \%$ (2.01 $\mathrm{g}$ dry $\mathrm{wt} \mathrm{m}^{-2}$ ) of the average biomass of all taxa. At the mouth reaches, three chironomid taxa, $M$. deribae, T. kharaensis and Ch. salinarius, constituted up to $95.3 \%\left(16,130\right.$ ind. $\left.\mathrm{m}^{-2}\right)$ of the average density and up to $81.1 \%\left(1.93 \mathrm{~g}\right.$ dry wt $\left.\mathrm{m}^{2}\right)$ of the average biomass of macrozoobenthos. 


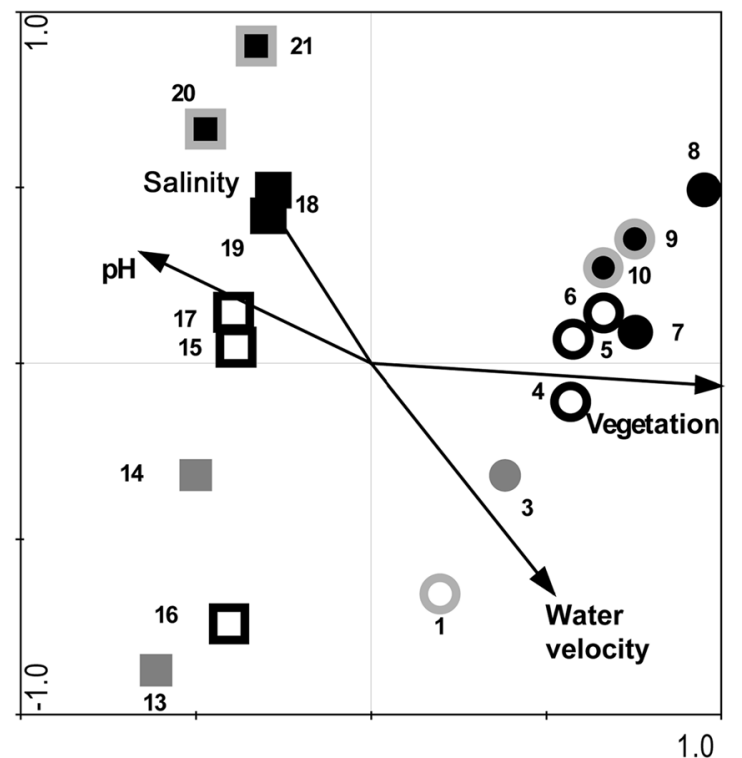

SAMPLES
S2 May
S2 June
(2) s2 Juy
S2 August
S3 July
S3 August
S2 September
S3 September

Fig. 2 CCA biplot of the relationship between the four significant environmental variables and the taxonomic composition of macrozoobenthos in the middle (S1) and the mouth section (S2) of the B. Samoroda River during the different months of the vegetation season

\section{Growth rates, production and production/biomass ratio $(P / B)$}

Daily growth rates estimated by the temperaturedependent growth equations were very high for Chironomidae taxa. Growth rates for this group were usually at least $0.03 \mathrm{~d}^{-1}$ and sometimes (in June, Site 2) exceeded 0.5 day $^{-1}$ (Table 7). For other insects, the growth rate was lower, varying from 0.012 to 0.378 day $^{-1}$.

In both habitats, the production for the whole study period ranged between $0.67 \mathrm{~g}$ dry wt $\mathrm{m}^{-2}$ month $^{-1}$ (at Site 1 in January) and $44 \mathrm{~g}$ dry wt $\mathrm{m}^{-2}$ month $^{-1}$ (at Site 2 in July) (Fig. 5). The production was the lowest in both sites in winter and early spring when the water temperature was $\leq 8.5^{\circ} \mathrm{C}$. The highest production peak of $6.13 \mathrm{~g}$ dry wt $\mathrm{m}^{-2}$ month $^{-1}$ was at Site 1 in June at $25.6{ }^{\circ} \mathrm{C}$, and at Site 2 , it was $44 \mathrm{~g}$ dry wt $\mathrm{m}^{-2}$ month $^{-1}$ in July at $26^{\circ} \mathrm{C}$.

The average production of all taxa for the year was much higher at Site 2 and reached $117 \mathrm{~g}$

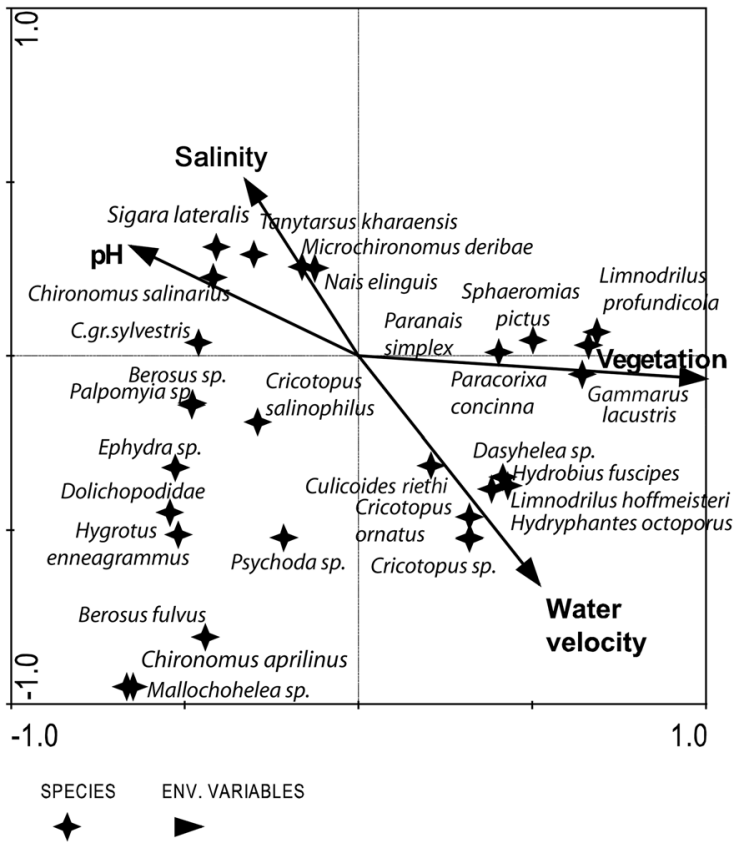

Fig. 3 CCA biplot of the relationship between the four significant environmental variables and the species of macrozoobenthos of the B. Samoroda River

dry $\mathrm{wt} \mathrm{m}^{-2} \mathrm{yr}^{-1}$, while at Site 1 , it reached only $22.54 \mathrm{~g}$ dry $\mathrm{wt} \mathrm{m}^{-2} \mathrm{yr}^{-1}$ (Tables 2, 3).

In all seasons of the year at both sites, the same taxonomic groups of macrozoobenthos contributed the most to benthic production. Diptera dominated in both places, while the Amphipoda dominated only at Site 1. In the middle reaches, three taxa, G. lacustris, S. pictus and $\quad$ G. salinus, constituted $82.5 \%$

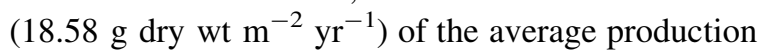
of all taxa. At the river mouth, M. deribae, $T$. kharaensis and Ch. salinarius constituted up to $86.4 \%$ of the average production of all taxa (101.1 g dry wt $\left.\mathrm{m}^{-2} \mathrm{yr}^{-1}\right)$.

The highest values for the production/biomass $(P /$ $B)$ ratio during the year were recorded for Diptera species: 95 for T. kharaensis, 86 for Ephydra sp., 85 for Psychoda sp., 76 for $M$. deribae, 70 for $C$. salinophilus, 68 for C. ornatus and 51 for $C h$. salinarius (Tables 2, 3). For other groups of macrozoobenthos, $P / B$ varied from 3 to 16 .

The concentration of chlorophyll- $a$ in the middle reach of the B. Samoroda River reached $19.4 \mathrm{mg} \mathrm{m}^{-3}$, and at the river mouth, it reached $18.8 \mathrm{mg} \mathrm{m}^{-3}$, reflecting high biomass and phytoplankton production in both sections of the river (Table 1). 

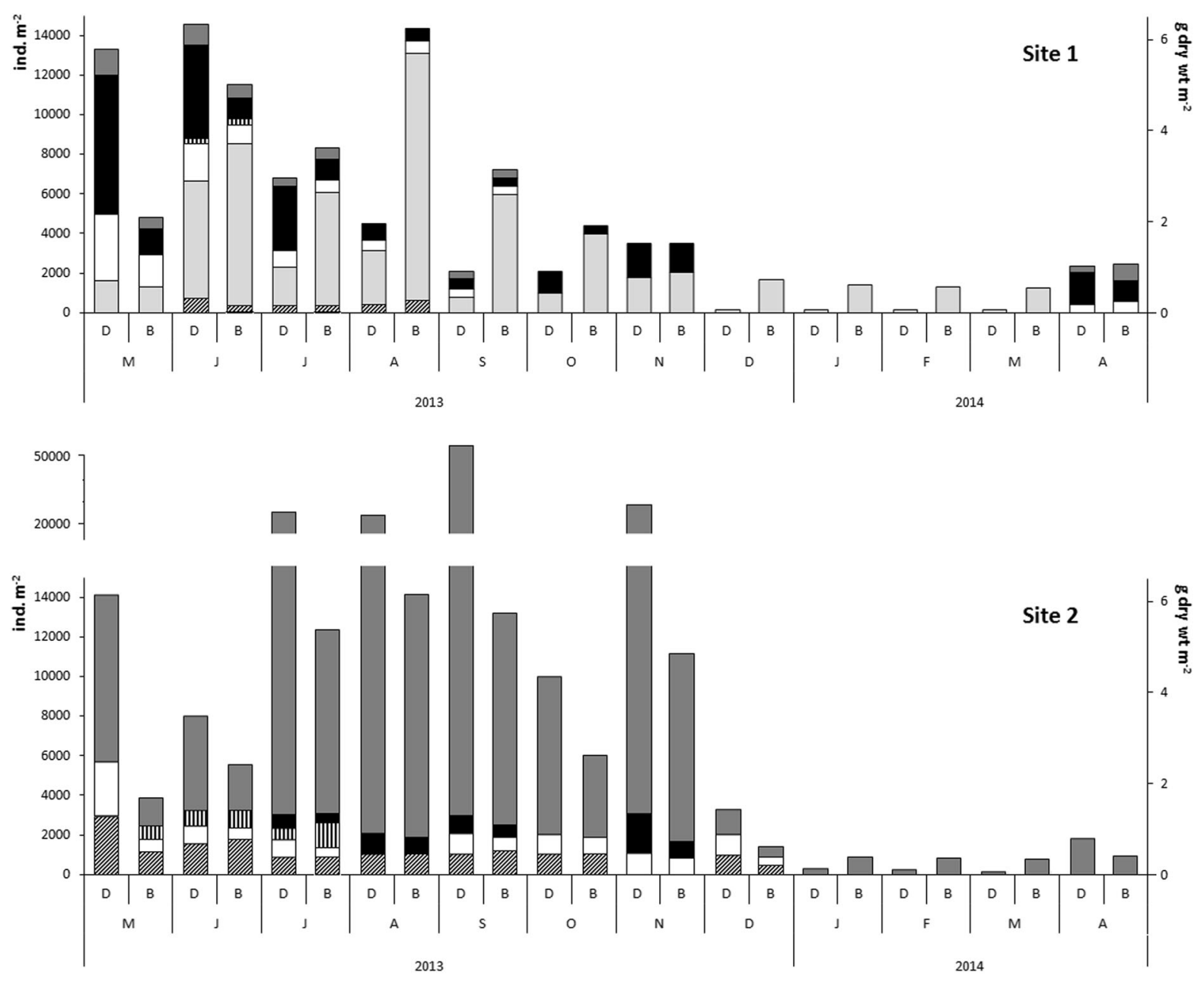

$\square$ Chironomidae $\quad$ Oligochaeta $\quad$ ll Coleoptera $\quad \square$ Ceratopogonidae $\square$ Gammaridae others

Fig. 4 Dynamic of density $(D)$ and biomass $(B)$ of the main groups of macrozoobenthos at the two sampling sites in the B. Samoroda River from May 2013 to April 2014

Number of Gammarus lacustris generations

Large, mature females of G. lacustris that represented the generation of the previous year and have eggs in brood chambers were found in May 2013 at a water temperature of $22{ }^{\circ} \mathrm{C}$. Young individuals that emerged from these eggs developed during the year and reached sexual maturity by May 2014. At this time, large females with eggs in the brood chambers were found again in the population of Gammarus lacustris. In other months of the year, sexually mature females were not found. Thus, we suppose that the population of $G$. lacustris in the saline river B. Samoroda produces only one generation per year.

\section{Discussion}

Studies of ecosystem function in saline rivers are rare despite the high ecological importance of these rivers for the surrounding terrestrial ecosystems. Such investigations in arid regions are especially important in view of modern climate change and aridification of the climate in many regions on Earth (IPCC 2017). In our study, for the first time, we estimated the production of macrozoobenthos communities in saline rivers of the Lake Elton basin (Lower Volga Region), which is an important resting place for migratory birds. 
Table 7 Growth rate $\left(G\right.$, day $^{-1}$, min-max) of main groups of insects in B. Samoroda River at Sites 1 and 2 from May 2013 to April 2014 as estimated by the temperature-dependent growth equations

\begin{tabular}{llllll}
\hline Taxa & \multicolumn{2}{l}{ Site 1} & & & \multicolumn{2}{l}{ Site 2 } & \\
\cline { 2 - 3 } & Min & Max & & Min & Max \\
\hline Orthocladiinae & 0.177 & 0.273 & & 0.039 & 0.347 \\
Chironominae & 0.03 & 0.371 & & 0.033 & 0.501 \\
Ceratopogonidae & 0.011 & 0.078 & 0.012 & 0.099 \\
Diptera (others) & 0.285 & 0.285 & 0.202 & 0.378 \\
Coleoptera & 0.051 & 0.051 & 0.041 & 0.061 \\
Heteroptera & 0.05 & 0.078 & 0.017 & 0.081 \\
\hline
\end{tabular}

Fauna

In the investigated B. Samoroda River, Diptera showed the highest diversity in comparison with other groups of invertebrates. The same was found in other saline rivers of arid regions (Bunn and Davies 1992; Gallardo-Mayenco 1994; Velasco et al. 2006; Zerguine 2014). In contrast, Plecoptera, Ephemeroptera, Trichoptera and Hirudinea, which are usually widespread in fresh waters, were not found in the B. Samoroda River at all. Apparently, this is due to the low-salinity tolerance of these taxonomic groups (Lukin 1976; Lepneva 1964; Hart et al. 1991). However, it was found in the rivers of Australia, Canada, Spain, France and Germany that some species of these groups could survive at salinities of up to 4-8 $\mathrm{g} \mathrm{l}^{-1} \quad$ (leeches), 2-9 $\mathrm{g} \mathrm{l}^{-1}$ (stoneflies) and
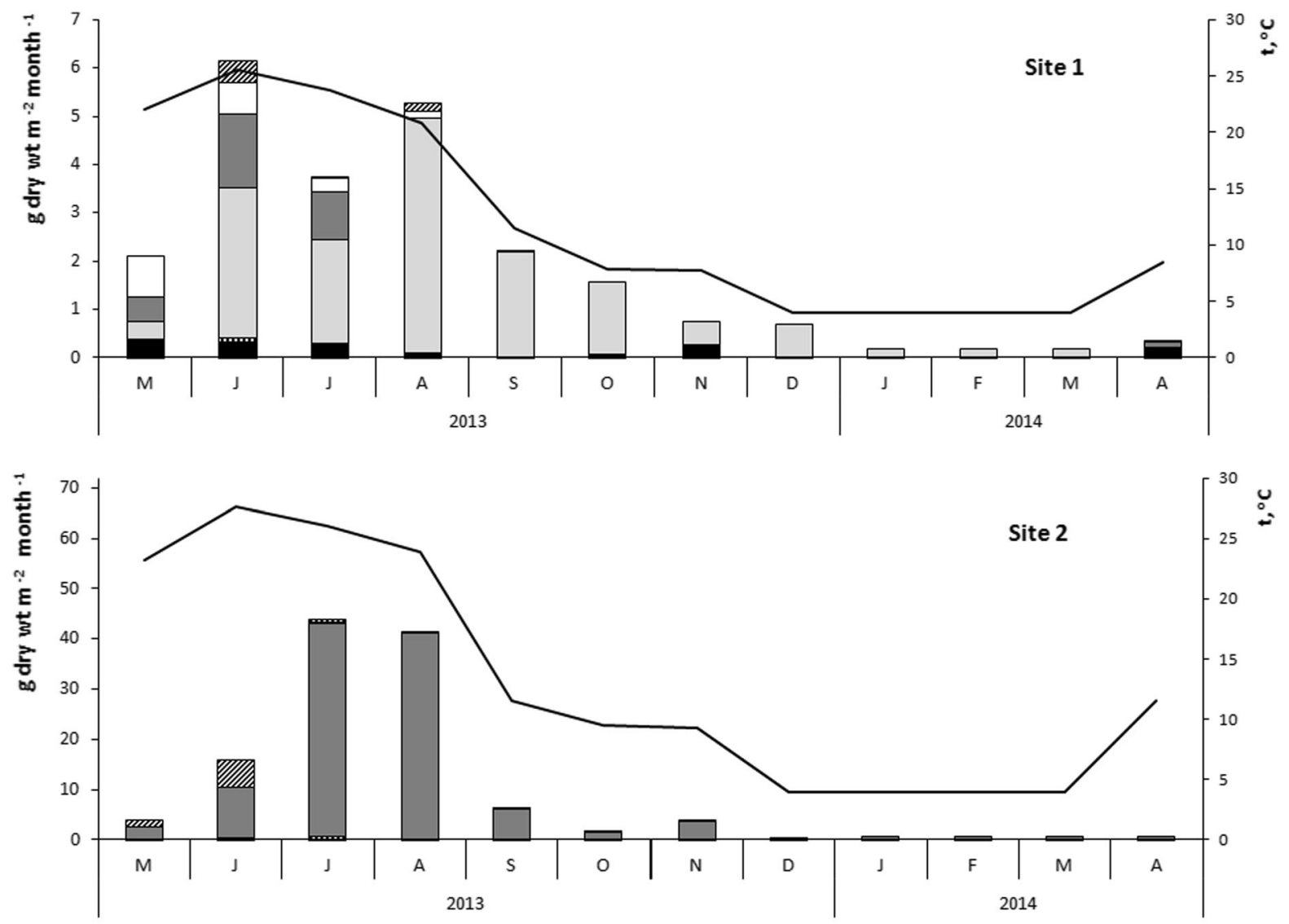

Oligochaeta mWmColeoptera $\square$ Gammaridae $\square$ Chironomidae $\square$ Ceratopogonidae שmothers $\square$ temperature

Fig. 5 Dynamics of production of the main groups of macrozoobenthos at two sampling sites of the B. Samoroda River from May 2013 to April 2014 
9.2-75 $\mathrm{g} \mathrm{l}^{-1}$ (mayflies) (Short et al. 1991; GallardoMayenco 1994; Ubero-Pascal et al. 1998; Kay et al. 2001; Rutherford and Kefford 2005; Velasco et al. 2006).

Among Diptera, the permanent inhabitants of the B. Samoroda River were Chironomidae, Ceratopogonidae, Ephydridae and Psychodidae. Species of these families are widespread in saline waters of the world (Armitage et al. 1994; Velasco et al. 2006; Przhiboro 2014; Shadrin et al. 2017). Chironomid larvae were found in rivers with salinity up to $115 \mathrm{~g} \mathrm{l}^{-1}$ (Rutherford and Kefford 2005), Ceratopogonid larvae can tolerate salinity up to $108 \mathrm{~g}^{-1}$ (Rutherford and Kefford 2005) and Ephydridae larvae up to $100 \mathrm{~g}^{-1}$ (Velasco et al. 2006).

The most abundant species in the B. Samoroda River, M. deribae, is a typical brackish water species. Larvae of this species were found in waters with a salinity of up to $42 \mathrm{~g} \mathrm{l}^{-1}$ (Laville and Toureno 1967). Ch. salinarius, which has a very high abundance in the river mouth, is known to be a halophilous organism inhabiting saline and brackish waters (Cartier et al. 2010; Estrella and Masero 2010). This species was also found in Europe, America and Asia (Fuentes et al. 2005; Ree and Yum 2006). Ch. salinarius and $M$. deribae usually inhabit coastal marine lagoons (Krebs 1979; Ceretti et al. 1987; Drake and Arias 1995). In contrast, T. kharaensis was first described by us in the rivers of the Lake Elton basin (Zorina and Zinchenko 2009) and is probably subendemic.

Among the other dipterans in the middle reaches of the B. Samoroda River, the Ceratopogonide S. pictus develops dense populations. This is a common arboreal species widely distributed in the Palaearctic (Szadziewski et al. 2007). Larvae are common in fresh waters and in highly mineralized lakes and ponds (Moller Pillot 2013).

Oligochaeta in the B. Samoroda River were represented by the families Naididae and Tubificidae, which were also found in Australian rivers with salinity of up to $39.6 \mathrm{~g} \mathrm{l}^{-1}$ (Tubificidae) and of up to $22.6 \mathrm{~g} \mathrm{l}^{-1}$ (Naididae) (Rutherford and Kefford 2005). Oligochaetes $L$. profundicola and $N$. elinguis reached very high abundances in the B. Samoroda River. Euryhaline L. profundicola is known from the profundal of Lake Baikal (Timm 2012), in lakes and rivers of Kamchatka and in the southern areas of the Russian Far East (Semernoi and Sidorov 1913),
Western Europe (Atanackovic et al. 2013), North America (Popchenko 1988) and Japan (Ohtaka 2014).

Nais elinguis is widely distributed in fresh and brackish waters. It has been found in cold-water rivers and streams, tidal littoral zones of lakes, in littoral areas of the White Sea and in lakes of the tundra (Popchenko 1988), as well as in warm ponds and channels of Central Asia (Chekanovskaya 1962). Nais elinguis also inhabits reservoirs of Western Europe, North and South America (Christoffersen 2007) and China (Wang and Cui 2007).

Beetle larvae are rare in the B. Samoroda River. Species of the genus Berosus have the highest density in the river mouth. Species of this genus are common in saline rivers (Velasco et al. 2006), in retention tanks, in ponds and in temporary reservoirs exposed to salinization (Prokin 2008). Species of the Hydrophilidae and Dytiscidae families (Coleoptera) that were found in the B. Samoroda River are common in the saline rivers of Spain and southeastern Australia, where they inhabit waters with salinities up to 81-135 $\mathrm{g} \mathrm{l}^{-1}$ (Bunn and Davies 1992; GallardoMayenco 1994; Kay et al. 2001; Rutherford and Kefford 2005; Velasco et al. 2006).

Among the Heteroptera, only Corixidae were found. They are known for inhabiting waters with salinities of up to 2.60-100 $\mathrm{g} \mathrm{l}^{-1}$ in rivers of other arid regions of the world (Gallardo-Mayenco 1994; Kay et al. 2001; Piscart et al. 2005; Rutherford and Kefford 2005; Barahona et al. 2005).

Crustaceans were represented only by G. lacustris, a species that is widely distributed in fresh and saline waters (Väinölä et al. 2007).

Thus, at the level of families and some species, the fauna of the saline B. Samoroda River demonstrated similarities with the fauna of saline water bodies from other arid regions across the world. This indicates specialization of the found taxa to salty environments.

Biomass and production of macrozoobenthos

The average total biomass of macrozoobenthos at both sites was similar; however, there was a great difference in the production of benthic communities. It was influenced by differences in abiotic factors, especially the presence of macrophytes, flow water velocity, salinity and $\mathrm{pH}$, which played a decisive role in defining the species composition and the dominance of individual species. 
In the middle reach of the river under flowing water conditions, at lower salinity (up to $8.5 \mathrm{~g} \mathrm{l}^{-1}$ ), and in the presence of macrophytes, the amphipods $G$. lacustris developed mass populations. G. lacustris are frequently dominant or subdominant (Grabowskyi et al. 2007; Zadereev et al. 2010). Our study has shown that populations of this species have only one generation per year in the B. Samoroda River. This is consistent with the data obtained for the populations of G. lacustris living in rivers in Europe, where this species is also univoltine (Hynes and Harper 1992; Grabowskyi et al. 2007).

The calculated annual $P / B$ coefficient for the univoltine amphipod $G$. lacustris was relatively low $(P / B=8)$, suggesting that the population of this species was characterized by a low reproduction rate, which resulted in lower macrozoobenthos production in the middle reach of the river in comparison with the river mouth.

In the mouth reaches, where salinity was higher (up to $26.3 \mathrm{~g} \mathrm{l}^{-1}$ ) and macrophytes had lower density, the chironomids $M$. deribae, Ch. salinarius, T. kharaensis and $C$. salinophilus had high biomass. These species, such as many other chironomid taxa, have a multivoltine life cycle. Our earlier study, in which we reared Ch. salinarius and C. salinophilus from eggs to adults in laboratory conditions (Golovatyuk and Zinchenko 2015), showed that C. salinophilus can develop 7-8 generations per year, and Ch. salinarius can have 3-4 generations per year. Our results indicated that larvae of these species have higher biomass turnover and therefore higher production. Conceivably, high production of chironomid larvae may be a characteristic of many brackish and saline waters. For instance, in a brackish pond of a coastal lagoon system of the northern Adriatic Sea (Italy), annual production of $C h$.

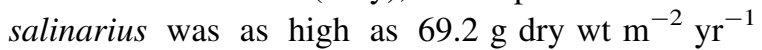
(Ponti et al. 2007).

The data on the production of bottom communities of saline rivers are available only for some groups of hydrobionts, such as Chironomidae, Ceratopogonidae and Corixidae (Barahona et al. 2005; Zinchenko et al. 2014; Golovatyuk et al. 2018). The annual production for the study period in the saline B. Samoroda River was much higher than the annual production of some freshwater rivers and lakes. For example, the annual production of macrozoobenthic fauna of the Lambourn River (Southern England) was $22.55 \mathrm{~g}$ dry wt $\mathrm{m}^{-2} \mathrm{yr}^{-1}$ (Tod and Schmid-Araya 2009). In a
Canadian cold-water spring-brook system (Toronto, Ontario), the annual production of macrozoobenthos was $11.21 \mathrm{~g}$ dry $\mathrm{wt} \mathrm{m}^{-2} \mathrm{yr}^{-1}$ in the upstream area and $4.01 \mathrm{~g}$ dry $\mathrm{wt} \mathrm{m}^{-2} \mathrm{yr}^{-1}$ in the downstream area (Williams and Hogg 1988). In the Yangtze floodplain (China), the annual production of macrozoobenthos

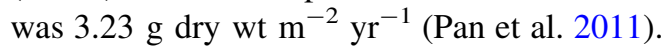

However, in a brackish coastal lagoon of the northern Adriatic Sea (Italy), the production of macrozoobenthos reached up to $152.6 \mathrm{~g}$ dry $\mathrm{wt}^{-2}$ $\mathrm{yr}^{-1}$ (Ponti et al. 2007). Our study has shown that macrozoobenthos production in the less-saline middle reaches of the B. Samoroda River was comparable or 2-5 times higher than production in fresh water. Production in the more saline mouth reaches was 5-29 times higher than in fresh water and similar to the production of brackish waters.

Density, biomass, production and $P /$

$B$ of chironomid larvae populations

The larvae of Chironomidae comprise one of the most important components of the macroinvertebrate community in the mouth reaches of the B. Samoroda River, where waterfowl has high density. Here, chironomids have a high density and constitute $97 \%$ of the total density, $91 \%$ of the total biomass and $92 \%$ of the total production of zoobenthos.

The observed high density of chironomid larvae in the mouth reaches of the saline B. Samoroda River exceeds or is comparable to that of other important rest stops for migratory waders in Europe, for example, Kirov Bay on the southwest coast of the Caspian Sea (Kyzylagachsky nature reserve) (Shubin 1998), Sylvas Bay, the Sea of Asov (Chernichko and Kirikova 1999), Kalmykia (southwestern Russia; Shubin and Ivanov 2005), Hungary (Székely and Bamberger 1992) or Great Britain (Goss-Custard 1977). The annual production of chironomid larvae in different regions of the world varies considerably. In the cold-water Lambourn River (Southern England), chironomid production was $0.36 \mathrm{~g}^{\mathrm{dry}} \mathrm{wt} \mathrm{m}^{-2} \mathrm{yr}^{-1}$ (Tod and Schmid-Araya 2009), and in the Canadian cold-water spring-brook system, it was 0.36 and $0.67 \mathrm{~g}$ dry wt $\mathrm{m}^{-2} \mathrm{yr}^{-1}$ in the upstream and downstream areas, respectively (Williams and Hogg 1988). The annual production of chironomid larvae in Rocky Mountain streams did not exceed $0.81 \mathrm{~g}$ dry wt $\mathrm{m}^{-2} \mathrm{yr}^{-1}$ (Carlisle and Clements 2003). In two polluted 
midlatitude Polish rivers (the Widawka River and the Grabia River), the annual production of chironomids was approximately $25 \mathrm{~g}_{\text {dry }} \mathrm{wt} \mathrm{m}^{-2} \mathrm{yr}^{-1}$ (Grzybkowska 1989). In a subtropical stream in China, the annual production of chironomid larvae was approximately $35.6 \mathrm{~g}$ dry $\mathrm{wt} \mathrm{m}^{-2} \mathrm{yr}^{-1}$ (Yan and Li 2006), and in a coastal plain blackwater river, the annual production of chironomid larvae was twice as high as even the production in eutrophic and warm-water rivers and reached $82 \mathrm{~g}$ dry $\mathrm{wt} \mathrm{m}^{-2} \mathrm{yr}^{-1}$ (Benke et al. 1998).

Our earlier study has shown that average content of the essential long-chain fatty acids (HUFA) in $C$. salinophilus was $18.2 \mathrm{mg} \mathrm{g}^{-1} \mathrm{dry} \mathrm{wt}$, and in $C h$. salinarius + Ch. aprilinus it was $3.5 \mathrm{mg} \mathrm{g}^{-1}$ dry wt. The average content of EPA (Eicosapentaenoic) in the chironomid larvae was $10.8 \mathrm{mg} \mathrm{g}^{-1}$ dry wt (Zinchenko et al. 2014). Production of these species was $16.7 \mathrm{~g}$ dry wt $\mathrm{m}^{-2}$ month $^{-1}$ in August 2006-2010 and the monthly flux of EPA from the studied rivers of Lake Elton basin to land due to chironomid potential emergence was $33 \mathrm{mg} \mathrm{m}^{-2}$ month $^{-1}$, which is roughly comparable to the global average estimation of annual water-land HUFA export via emerging insects $(40 \mathrm{mg}$ $\mathrm{m}^{-2}$ month ${ }^{-1}$; Gladyshev et al. 2009). Calculated annual production only three species $C$. salinophilus, Ch. salinarius and Ch. aprilinus in the B. Samoroda River was $41.9 \mathrm{~g}$ dry wt $\mathrm{m}^{-2} \mathrm{yr}^{-1}$ which significantly exceed the average estimate of annual water-land HUFA export and give evidence for a high importance of chironomid productivity from saline B. Samoroda River for surrounding terrestrial habitats.

Comparison of the production of chironomid larvae in the saline B. Samoroda River with that of rivers from other regions of the world has demonstrated that production of chironomid larvae in the mouth reaches of the B. Samoroda River was much higher than that of any of these rivers, accounting for $108.2 \mathrm{~g}$ dry wt $\mathrm{m}^{-2} \mathrm{yr}^{-1}$, which can be considered extremely productive (hyper-eutrophic) (Tokeshi 1995).

The concentrations of chlorophyll- $a$ indicate a high biomass of microalgae in the B. Samoroda River (Table 1). This, together with thick silt deposits that are characteristic of estuaries of saline rivers (Vodnobolotnye 2005), constitutes a rich food source for bacterivorous organisms and contributes considerably to the high production of chironomid larvae in saline rivers (Zinchenko et al. 2014). Additionally, we suggest that the high water temperatures $\left(8.5-27.6{ }^{\circ} \mathrm{C}\right)$ observed during the growing season (from April to September) could play an important role in the high production of hydrobionts in the B. Samoroda River.

Max $P / B$ values of chironomid populations in the mouth reaches of the B. Samoroda River are comparable to the highest average annual $P / B$ ratio in freshwater rivers (Benke and Huryn 2017). For example, in the Satilla River (USA), the annual $P$ / $B$ ratio for the Tanytarsini group was 176-184, and the annual $P / B$ ratio for the Cricotopus group was 99-118 (Benke et al. 1984). In Polish rivers, the annual $P /$ $B$ ratio for Cladotanytarsus sp. was $45-46$, and for Polypedilum sp. it was 32-34 (Benke et al. 1984; Grzybkowska 1989).

Usually, benthic fauna of saline waters, like those investigated in our study of the B. Samoroda River, is characterized by a small number of highly specialized species (Velasco et al. 2006). They are adapted to extreme salinity and are able to develop populations of very high density and biomass (Bunn and Devis 1992; Velasco et al. 2006) due to low interspecies competition (Zinchenko et al. 2014; Golovatyuk et al. 2018). This, together with the high availability of food resources for chironomid larvae and other hydrobionts, leads to high production of macrozoobenthos, as seen in the saline B. Samoroda River.

However, our earlier study in the Elton Lake catchment showed that during periods of sharp increases in the salinity of rivers due to the influx of hypersaline water from Lake Elton, the abundance and biomass of major species of macrozoobenthos decrease significantly (Zinchenko et al. 2012). During these periods, the rise of water salinity up to 100-200 $\mathrm{g}^{-1}$ leads to death or massive upstream movement of such chironomid species as T. kharaensis, M. deribae and Ch. salinarius (Zinchenko et al. 2012). It is likely that surging phenomena and water exchange with water bodies of higher salinity are among the critical factors limiting the production of hydrobionts in the estuaries of saline rivers.

\section{Conclusions}

Macrozoobenthic fauna of the saline B. Samoroda River is represented by 30 euryhaline and halophilic taxa of benthic macroinvertebrates. The taxonomic 
composition of macrozoobenthos in the middle reaches and at the mouth of the B. Samoroda River differed significantly, which was caused by differences in major abiotic factors affecting hydrobionts, such as the presence of vegetation, water flow velocity, $\mathrm{pH}$ of the water and salinity, at both sites.

In seasonal dynamics, a stable high density of macrozoobenthos was observed in the middle reach from May to August with the highest abundances in June and at the river mouth from May to November with the highest abundances in September. The lowest abundances were found in winter and early spring at both study sites (March and April).

The highest production in the benthic communities at the mouth of the saline B. Samoroda River is provided by multivoltine chironomid species $T$. kharaensis, $M$. deribae and $C$. salinarius, which have higher biomass turnover. The production of the benthos at the middle reach was lower than at the mouth reach due to the dominance of the univoltine population of crustaceans G. lacustris at the middle reach.

Our analysis showed that the calculated annual production of benthic invertebrates in the B. Samoroda River was comparable with the annual production in brackish waters of other regions of the world and was several times higher than the production of freshwater river benthic communities. The saline B. Samoroda River play an important role for surrounding terrestrial habitats due to high production of macrozoobenthos communities and especially of chironomid larvae that provide high annual water-land HUFA export.

Acknowledgements This research was supported by Russian Foundation for Basic Research (RFBR) (Projects Numbers 13-04-00740, 15-04-03341, 17-04-00135). LN is supported by the Deutsche Forschungsgemeinschaft (DFG) Project NA 760/5-1. Statistical study is supported by the Russian Science Foundation (Grant 16-17-10118). We are grateful to E.V. Makarchenko and O.V. Zorina for assistance in determining Chironomidae family, A.A. Prokin for assistance in determining the Coleoptera and Heteroptera groups, T.V. Popchenko for determining Oligochaeta group and E.M. Kurina for helping in determining the number of generations of Gammarus lacustris.

\section{References}

Andrei AE, Smith LM, Haukos DA, Surles JG, Johnson WP (2009) Foraging ecology of migrant shorebirds in saline lakes of the Southern Great Plains. Int J Waterbird Biol 32:138-148
Armitage PD, Pinder LCV, Cranston PS (1994) Biology and ecology of non-biting midges. Chapman \& Hall, London

Atanackovic AD, Šporka F, Csányi B, Vasiljevic BM, Jelena M, Tomovic JM, Paunovic MM (2013) Oligochaeta of the Danube River-a faunistical review. Biologia 68(2):269-277. https://doi.org/10.2478/s11756-013-01559

Ballinger A, Lake PS (2006) Energy and nutrient fluxes from rivers and streamsinto terrestrialfood webs. Mar Freshw Res 57:15-28. https://doi.org/10.1071/MF05154

Barahona J, Millán A, Velasco J (2005) Population dynamics, growth and production of Sigara selecta (Fiebre, 1848) (Hemiptera, Corixidae) in a Mediterranean hypersaline stream. Freshwat Biol 50:2101-2113. https://doi.org/10. 1111/j.13652427.2005.01463.x

Baxter CV, Fausch KD, Saunders WC (2005) Tangled webs: reciprocal flows of invertebrate prey link streams and riparian zones. Freshwat Biol 50:201-220. https://doi.org/ 10.1111/j.1365-2427.2004.01328.x

Bazikalova AY (1945) Amphipods of Lake Baikal. Proc Baikal Limnol Stn USSR Acad Sci 11:1-440

Benke AC (1998) Production dynamics of riverine chironomids: extremely high biomass turnover rates of primary consumers. Ecology 79:899-910

Benke AC, Huryn AD (2010) Benthic invertebrate productionfacilitating answers to ecological riddles in freshwater ecosystems. J N Am Benthol Soc 29(1):264-285. https:// doi.org/10.1899/08-075.1

Benke AC, Huryn AD (2017) Secondary production and quantitative food webs In: Methods in stream ecology. 3rd ed. Ecosystem function. Academic Press, Cambridge, vol 2, pp 235-254

Benke AC, Van Arsdall TC Jr, Gillespie DM (1984) Invertebrate productivity in a subtropical Blackwater River: the importance of habitat and life history. Ecol Monograph 54(1):25-63

Birks HJB (1995) Quantitative palaeoenvironmental reconstructions. In: Maddy D, Brew JS (eds) Statistical modelling of quaternary science data. Technical Guide 5, Quaternary Research Association, Cambridge, pp 161-254

Brown S, Hickey C, Harrington B, Gill R (2001) United states shorebird conservation plan, 2nd edn. Manomet Center for Conservation Sciences, Manomet

Bunn SE, Davies PM (1992) Community structure of the macroinvertebrate fauna and water quality of a saline river system in south-western Australia. Hydrobiologia 248:143-160

Carlisle DM, Clements WH (2003) Growth and secondary production of aquatic insects along a gradient of $\mathrm{Zn}$ contamination in Rocky Mountain streams. J N Am Benthol Soc 22:582-597

Cartier V, Claret C, Garnier R, Fayolle S, Franquet E (2010) Multi-scale approach to the environmental factors effects on spatio-temporal variability of Chironomus salinarius (Diptera: Chironomidae) in a French coastal lagoon. Estuar Coast Shelf S 86:637-644

Ceretti G, Ferrarese U, Francescon A, Barbaro A (1987) Chironomids (Diptera: Chironomidae) in the natural diet of gilthead seabream (Sparus aurata L.) farmed in the Venice lagoon. Ent Scand Suppl 29:289-292 
Chekanovskaya OV (1962) Aquatic small-necked worms of the USSR fauna. Determinants on the fauna of the USSR, published by the Zoological Institute of the Academy of Sciences of the USSR. M.-L.: Publishing House of the Academy of Sciences of the USSR

Chernichko II, Kirikova TA (1999) Macrozoobenthos Sivash and the associated placement of waders. Fauna, ecology and protection of birds of the Azov-Black Sea region. Sat scientific works. Sonat, Simferopol, pp 230-257

Christoffersen ML (2007) A catalogue of aquatic microdrile oligochaetes (Annelida: Clitellata) from South America. Acta Hydrobiol Sin 31:59-86

Drake P, Arias AM (1995) Distribution and production of Chironomus salinarius (Diptera: Chironomidae) in a shallow coastal lagoon in the Bay of Cadiz. Hydrobiologia 299:195-206

Estrella SM, Masero JA (2010) Prey and prey size selection by the near-threatened black-tailed godwit foraging in nontidal areas during migration. Waterbirds 33:293-299

Fellows S, Stone K, Jones S, Damude N, Brown S (2001) Central Plains/Playa Lakes regional shorebird conservation plan: version 1.0. US Fish and Wildlife Service, Denver

Frolova LA, Nazarova L, Pestryakova L, Herzschuh U (2013) Analysis of the effects of climate-dependent factors on the formation of zooplankton communities that inhabit Arctic Lakes in the Anabar River basin. Contemp Probl Ecol 6(1):1-11

Fuentes C, Green AJ, Orr J, Olafsson JS (2005) Seasonal variation in species composition and larval size of the benthic chironomid communities in brackish wetlands in Southern. Alicante, Spain. Wetlands 25:289-296

Gallardo-Mayenco A (1994) Freshwater macroinvertebrate distribution in two basins with different salinity gradients (Guadalete and Guadaira river basins, south-western Spain). Int J Salt Lake Res 3:75-91. https://doi.org/10. 1007/BF01990644

Gladyshev MI, Arts MI, Sushchik NN (2009) Preliminari estimates of the export of omega-3 highly unsaturated fatty acids (EPA+DHA) from aquatic to terrestrial ecosystems. In: Arts MT, Kainz M, Brett MT (eds) Lipids in aqutic ecosystems. Springer, New-York, pp 179-209

Golovatyuk LV, Shitikov VK (2016) Salinity tolerance of macrozoobenthic taxa in small rivers of the Lake Elton basin. Russ J Ecol 47:540-545. https://doi.org/10.1134/ S1067413616060059

Golovatyuk LV, Zinchenko TD (2015) Biological characteristics of the mass species of chironomids Cricotopus salinophilus and Chironomus salinarius from the saline rivers of Prieltonia: life cycles, specific production. Izv Sam NTS RAS 17:210-214

Golovatyuk LV, Zinchenko TD, Sushchik NN, Kalachova GS, Gladyshev MI (2018) Biological aspects of the associations of biting midges (Diptera: Ceratopogonidae) in two saline rivers of the Elton Lake basin. Mar Freshw Res, Russia. https://doi.org/10.1071/MF17125

Golubkov SM (2000) Functional ecology of the larvae of amphibiotic insects. Zoological Institute of RAS, St Petersburg

Goss-Custard JD (1977) The ecology of the Wash. III. Densityrelated behaviour and the possible effects of a loss of feeding grounds on wading birds (Charadrii). J Appl Ecol 14:721-739

Grabowskyi M, Baccela K, Konopacka A (2007) How to be an invasive gammarid (Amphipoda: Gammaroidea) - comparison of life history traits. Hydrobiologia 590:75-84. https://doi.org/10.1007/s10750-007-0759-6

Grzybkowska M (1989) Production estimates of the dominant taxa of Chironomidae (Diptera) in the modified, River Widawka and the natural, River Grabia, Central Poland. Hydrobiologia 179:245-259

Hart BT, Bailey P, Edwards R, Hortle K, James K, McMahon A, Meredith C, Swadling KM (1991) A review of the salt sensitivity of the Australian freshwater biota. Hydrobiologia 210:105-144

Hynes HBN, Harper F (1992) The life histories of Gammarus lacustris and $G$. pseudolimnaeus in southern Ontario. Crustaceana Supplement 3:329-341

Intergovernmental Panel on Climate Change (IPCC) (2017) IPCC Fifth Assessment Report (AR5) Observed climate change impacts database, version 2.01. NASA Socioeconomic Data and Applications Center (SEDAC), Palisades, NY. https://doi.org/10.7927/H4FT8J0X

International Wader Study Group (2003) Are waders worldwide in decline? Reviewing the evidence. Conclusions from the 2003 International Wader Study Group conference in Cб́diz, Spain. http://web.uct.ac.za/depts/stats/adu/ wsg/pdf/wsgbdec2003-cadiz_conclusions.pdf. Accessed 20 Dec 2004

Juggins S (2013) Quantitative reconstructions in palaeolimnology: new paradigm or sick science? Quat Sci Rev 64:20-32

Kasatkina YN, Shubin AO (2012) The influence off oragereserves on the behavior of migrating little stints (Calidrisminuta) on Elton Lake. Zool Zh 91:95-110

Kay WR, Halse SA, Scanlon MD, Smith MJ (2001) Distributions and environmental tolerances of aquatic macroinvertebrate families in the agricultural zone of southwestern Australia. J N Am Benthol Soc 20:182-199

Krebs BPM (1979) Microchironomus deribae (Freeman, 1957) (Diptera, Chironomidae) in the Delta region of the Netherlands. Hydrobiol Bull (Amsterdam) 13:144-151

Laville H, Tourento JN (1967) Contribution to the knowledge of three chironomids of Camargue and Marismas of Guadalquivir. Int J Lim 3:185-204

Lepneva SG (1964) Larvae and pupae of the suborder Annulipalpia. The Fauna of the Soviet Union: Caddis Flies, Nauka. Leningrad 2:1-560

Lukin EI (1976) Leeches of fresh and brackish water bodies. The Fauna of the Soviet Union: Leeches. Nauka, Leningrad

Moller Pillot HKM (2013) Chironomidae larvae of the Netherlands and adjacent lowlands. Biology and ecology of the Chironomini 2. KNNV Publishing, Zeist

Moore JW, Schindler DE, Carter JL, Fox J, Griffiths J, Holtgrieve GW (2007) Biotic control of stream fluxes: spawning salmon drive nutrient and matter export. Ecology 88:1278-1291

Moreno JL, Aboal M, Vidal-Abarca MR, Suárez ML (2001) Macroalgae and submerged macrophytes from fresh and saline waterbodies of ephemeral streams ('ramblas') insemiaridsouth-easternSpain. Mar Freshw Res 52:891-905. https://doi.org/10.1071/MF00008 
Nakano S, Hitoshi M, Noatoshi K (1999) Terrestrial—aquatic linkages: riparian arthropod inputs alter trophic cascades in a stream food web. Ecology 80:2435-2441

Nazarova L, Semenov VF, Sabirov RM, Efimov IY (2004) The state of bentic communities and water quality of Cheboksar Water reservoir. Water Resour 31(3):347-353

Nazarova L, Self A, Brooks SJ, van Hardenbroek M, Herzschuh U, Diekmann B (2015) Northern Russian chironomidbased modern summer temperature data set and inference models. Global Planet Change 134:10-25

Nazarova LB, Self AE, Brooks SJ, Solovieva N, Syrykh LS, Dauvalter VA (2017) Chironomid fauna of the lakes from the Pechora River basin (East of European part of Russian Arctic): ecology and reconstruction of recent ecological changes in the region. Contemp Probl Ecol 4:350-362

Nomokonova VI, Zinchenko TD, Popchenko TV (2013) Trophic condition of salty rivers in the basin of Lake Elton. Izv Sam NTS RAS 15(3):368-475

Ohtaka A (2014) Profundal Oligochaete faunas (Annelida, Clitellata) in Japanese lakes. Zoosymposia 9:24-35. https://doi.org/10.11646/zoosymposia.9.1.7

Palagushkina OV, Nazarova LB, Wetterich S, Shirrmaister L (2012) Diatoms from sediments of water bodies of Siberian Arctic. Contemp Probl Ecol 5(4):413-422

Palagushkina O, Wetterich S, Schirrmeister L, Nazarova L (2017) Modern and fossil diatom assemblages from Bol'shoy Lyakhovsky Island (New Siberian Archipelago, Arctic Siberia). Contemp Probl Ecol 4:380-394

Palmer GC, Bennett AF (2006) Riparian zones provide for distinct bird assemblages in forest mosaics of south-east Australia. Biol Conserv 130:447-457. https://doi.org/10. 1016/J.BIOCON.2006.01.006

Pan BZ, Wang HJ, Liang XM, Wang HZ (2011) Macrozoobenthos in Yangtze floodplain lakes: patterns of density, biomass, and production in relation to river connectivity. J N Am Benthol Soc 30(2):589-602. https:// doi.org/10.1899/10-025.1

Piscart C, Moreteau J-C, Beisel J-N (2005) Biodiversity and structure of macroinvertebrate communities along a small permanent salinity gradient (Meurthe River, France). Hydrobiologia 546:1-10. https://doi.org/10.1007/s10750005-4463-0

Ponti M, Colangelo MA, Ceccherelli VU (2007) Composition, biomass and secondary production of the macrobenthic invertebrate assemblages in a coastal lagoon exploited for extensive aquaculture: Valle Smarlacca (northern Adriatic Sea). Estuar Coast Shelf S 75:79-89. https://doi.org/10. 1016/j.ecss.2007.01.021

Popchenko VI (1988) Aquatic malleech worms (Oligochaeta limicola) Northern Europe. Nauka, Leningrad

Prokin AA (2008) Aquatic beetles (Coleoptera) of small rivers of the European part of Russia: diversity, biocenotic and indicator role. In: Ecosystems of small rivers: biodiversity, ecology, protection. Lectures and materials of reports of the All-Russian school-conference. Borok, pp 38-53

Przhiboro A (2014) Diversity and adaptations of immature Diptera in semiaquatic habitats at shorelines of hypersaline lakes in the Crimea, with a brief review of Diptera in mineralized bodies of water. Acta Geol Sin-Engl 88(s1):98-100. https://doi.org/10.1111/1755-6724.12266_ 22
Ree H, Yum J-H (2006) Redescription of Chironomus salinarius (Diptera: Chironomidae), nuisance midges that emerged in brackish water of Jinhae-man (Bay), Kyongsangnam-do, Korea. Korean J Parasitol 44(1):63-66. https://doi.org/10. 3347/kjp.2006.44.1.63

Rutherford JC, Kefford BJ (2005) Effects of salinity on stream ecosystems: improving models for macroinvertebrates. CSIRO Land and Water Technical Report 22/05, Canberra

Semernoi VP, Sidorov DA (1913) New data on the Oligochaeta fauna from the Giporei of watercourses in the south of Primorsky Krai. Amur Ecol J 3:244-247

Shadrin NV, Anufriieva EV, Belyakov VP, Bazhora AI (2017) Chironomidae larvae in hypersaline waters of the Crimea: diversity, distribution, abundance and production. Eur Zool J 84:61-72. https://doi.org/10.1080/11250003.2016. 1273974

Short TM, Black JA, Birge WJ (1991) Ecology of a saline stream: community responses to spatial gradients of environmental conditions. Hydrobiologia 226:167-178

Shubin AO (1998) Microbiotopic distribution of waders (Charadriiformes, Charadrii) in places forage accumulations on the southwest coast of the Caspian Sea. Russ J Zool $77(3): 325-336$

Shubin AO, Ivanov AP (2005) Ecological segregation of migrating waders on steppe reservoirs. European Russia. Russ J Zool 84(6):707-718

Sukharev EA (2015) Effect of food resources on the distribution and ecological separation of migrating shorebirds. Dissertation, Moscow State Pedagogical University

Szadziewski R, Gwizdalska-Kentzer M, Sontag E (2007) Predatory biting midges of the genus Sphaeromias (Diptera: Ceratopogonidae) in Europe. Pol $\mathrm{J}$ Entomol 76:293-302

Szadziewski R, Golovatyuk LV, Sontag E, Urbanek A, Zinchenko TD (2016) All stages of the Palaearctic predaceous midge Palpomyia schmidti Goetghebuer, 1934 (Diptera: Ceratopogonidae). Zootaxa 4137(1):85-94. https://doi.org/ 10.11646/ZOOTAXA.4137.1.6

Székely T, Bamberger Z (1992) Predation of waders (Charadrii) on prey populations: an exclosure experiment. J Anim Ecol 61(2):447-456

ter Braak CJF (1990) Update notes: CANOCO Version 3.10. Agricultural Mathematics Group, Wageningen

ter Braak CJF (1995) Ordination. In: Jongman RHG, ter Braak CJF, van Tongeren OFR (eds) Data analysis in community and landscape ecology. Cambridge University Press, Cambridge, pp 69-173

ter Braak CJF, Šmilauer P (2002a) CANOCO reference manual and canodraw for windows user's guide: software for canonical community ordination (version 4.5). Microcomputer Power, Ithaca, NY

ter Braak CJF, Šmilauer P (2002b) CANOCO for windows: software for community ordination (version 4.5). Microcomputer Power, Ithaca New York

Timm T (2012) Profundal oligochaete assemblages in Palaearctic lakes. Turk J Zool 36(1):121-131. https://doi. org/10.3906/zoo-1002-51

Tod SP, Schmid-Araya JM (2009) Meiofauna versus macrofauna: secondary production of invertebrates in a lowland chalk stream. Limnol Oceanogr 54:450-456 
Tokeshi M (1995) Production ecology. In: Armitage PD, Cranston PS, Pinder LCV (eds) The Chironomidae: biology and ecology of non-biting midges. Chapman and Hall, London, pp 269-296

Ubero-Pascal NA, Puig MA, Solar AG (1998) The mayflies from Segura River basin (S.E. Spain): Faunisticstudy (Insecta: Ephemeroptera). Bol Aso Esp Ent 22:151-170

Väinölä RJ, Witt DS, Grabowski M, Bradbury JH, Jazdzewski K, Sket B (2007) Global diversity of amphipods (Amphipoda; Crustacea) in freshwater. Freshwater Animal Diversity Assessment. Part Dev Hydrobiol Book Ser 198:241-255

Velasco J, Millán A, Hernández J, Gutiérrez C, Abellán P, Sánchez D, Ruiz M (2006) Response of biotic communities to salinity changes in a Mediterranean hyper stream. Saline Syst 2:12-15. https://doi.org/10.1186/1746-1448-2-12

Vodno-bolotnye ugod'ya Priel'ton'ya (Wetlands of cisElton region) (2005). Video-Khaitek, Volgograd

Wang HZ, Cui YD (2007) On the studies of Microdrile Oligochaeta and Aeolosomatidae (Annelida) in China: brief history and species checklist. Acta Hydrobiol Sin 31:87-98

Williams DD, Hogg ID (1988) The ecology and production of invertebrates in a Canadian coldwater spring. Holarctic Ecol 11:41-54

Yan Y, Li X (2006) Production dynamics and trophic basis of dominant chironomids (Diptera: Chironomidae) in a subtropical stream in China. J Freshw Ecol 21:439-448

Yemelyanova AY, Temerova TA, Degermendzhi AG (2000) Experimental Study of Nutrition and growth Gammarus lacustris Sars (Amphipoda, Gammaridae) of Oz. Shira (Khakassia). Inland Water Biol 4:86-93

Zadereev ES, Tolomeyev AP, Drobotov AV, Emeliyanova AY, Gubanov MV (2010) The vertical distribution and abundance of Gammarus lacustris in the pelagic zone of the meromictic lakes Shira and Shunet (Khakassia, Russia). Aquat Ecol 44(3):531-539

Zaika BE (1972) Specific production of water invertebrates. Naukova Dumka, Kiev

Zerguine K (2014) Chironomidae (Diptera: Insecta) of temporary salt lakes in the eastern Hauts Plateaux of Algeria. Experiment 25:1704-1710

Zinchenko TD, Golovatyuk LV, Gusakov VA (2012) Long-term dynamics of bottom communities in estuaries of saline rivers in the Lake Basin. El'ton. Problems of studying the marginal structures of biocenosis. Saratov University Press, Saratov

Zinchenko TD, Gladyshev MI, Makhutova ON, Sushchik NN, Kalachova GS, Golovatyuk LV (2014) Rivers provide arid landscapes with a considerable amount of biochemically valuable production of chironomid (Diptera) larvae. Hydrobiologia 722:115-128. https://doi.org/10.1007/ S10750-013-1684-5

Zinchenko TD, Golovatyuk LV, Abrosimova EV, Popchenko TV (2017) Macrozoobenthos in Saline Rivers in the Lake Elton Basin: spatial and Temporal Dynamics. Inland Water Biol 10(4):384-398

Zorina OV, Zinchenko TD (2009) A New Species of the Genus Tanytarsus van der Wulp (Dirtera, Chironomidae) from a Saline River in the Elton Lake Basin (Volgogradskaya oblast', Russia). Evraziat Entomol Z 8(1):105-110

Publisher's Note Springer Nature remains neutral with regard to jurisdictional claims in published maps and institutional affiliations. 